\title{
Article \\ Characterization of a Novel Family IV Esterase Containing a Predicted CzcO Domain and a Family V Esterase with Broad Substrate Specificity from an Oil-Polluted Mud Flat Metagenomic Library
}

\author{
Jong Eun Park ${ }^{1}$, Geum Seok Jeong ${ }^{1}$, Hyun Woo Lee ${ }^{1}$, Sung Kyum Kim ${ }^{2}$, Jungho Kim ${ }^{2}$ and Hoon Kim ${ }^{1,2, *(\mathbb{D})}$ \\ 1 Department of Pharmacy, and Research Institute of Life Pharmaceutical Sciences, \\ Sunchon National University, Suncheon 57922, Korea; 1200113@s.scnu.ac.kr (J.E.P.); \\ 1200058@s.scnu.ac.kr (G.S.J.); hwlee@rophibio.com (H.W.L.) \\ 2 Department of Agricultural Chemistry, Sunchon National University, Suncheon 57922, Korea; \\ kimsk0851@scnu.ac.kr (S.K.K.); jungho@scnu.ac.kr (J.K.) \\ * Correspondence: hoon@sunchon.ac.kr; Tel.: +82-617-503-751
}

check for updates

Citation: Park, J.E.; Jeong, G.S.; Lee, H.W.; Kim, S.K.; Kim, J.; Kim, H. Characterization of a Novel Family IV Esterase Containing a Predicted CzcO Domain and a Family V Esterase with Broad Substrate Specificity from an Oil-Polluted Mud Flat Metagenomic Library. Appl. Sci. 2021, 11, 5905. https://doi.org/10.3390/app11135905

Academic Editor: Cédric Delattre

Received: 4 June 2021

Accepted: 22 June 2021

Published: 25 June 2021

Publisher's Note: MDPI stays neutral with regard to jurisdictional claims in published maps and institutional affiliations.

Copyright: (C) 2021 by the authors. Licensee MDPI, Basel, Switzerland. This article is an open access article distributed under the terms and conditions of the Creative Commons Attribution (CC BY) license (https:/ / creativecommons.org/licenses/by/ $4.0 /)$.

\begin{abstract}
Two novel esterase genes, est $2 L$ and est $4 L$, were identified from a previously constructed metagenomic library derived from an oil-polluted mud flat sample. The encoded Est2L and Est4L were composed of 839 and 267 amino acids, respectively, without signal peptides. Est2L was a unique fusion type of protein composed of two domains: a domain of the $\mathrm{CzcO}$ superfamily, associated with a cationic diffusion promoter with $\mathrm{CzcD}$, and a domain of the acetylesterase superfamily, belonging to family IV with conserved motifs, such as HGG, GXSAG, and GXPP. Est2L was the first fused esterase with a CzcO domain. Est4L belonged to family V with GXS, GXSMGG, and PTL motifs. Native Est2L and Est4L were found to be in dimeric and tetrameric forms, respectively. Est2L and Est4L showed the highest activities at $60{ }^{\circ} \mathrm{C}$ and $50{ }^{\circ} \mathrm{C}$, respectively, and at a $\mathrm{pH}$ of 10.0. Est2L preferred short length substrates, especially $p$-nitrophenyl (pNP)-acetate, with moderate butyrylcholinesterase activity, whereas Est4L showed the highest activity with pNP-decanoate and had broad specificity. Significant effects were not observed in Est2L from $\mathrm{Co}^{2+}$ and $\mathrm{Zn}^{2+}$, although Est2L contains the domain CzcD. Est2L and Est4L showed high stabilities in 30\% methanol and 1\% Triton X-100. These enzymes could be used for a variety of applications, such as detergent and mining processing under alkaline conditions.
\end{abstract}

Keywords: metagenomic library; CczO-containing family IV esterase; family V esterase; substrate specificity

\section{Introduction}

Lipolytic enzymes, such as esterase (EC 3.1.1.1) and lipase (EC3.1.1.3), are ubiquitous and hydrolyze small ester-containing molecules and insoluble long-chain triglycerides, respectively, yielding hydroxyl and carboxylate groups [1]. Lipases hydrolyze ester bonds in long-chain fatty acids (>10 carbons), whereas esterases hydrolyze ester bonds in shortchain fatty acids (<10 carbons). The application of esterases and lipases have been of interest in several industries, such as food, detergent, oil and fat, pulp and paper, leather, cosmetics, biodiesel production, textiles, and pharmaceuticals [2,3]. In addition, esterase usage for ester prodrugs has been used for cleaving and reactivation [4].

Due to their diversity, bacterial esterases and lipases have been widely studied, including their purification and biochemical properties [5,6]. The first classification of bacterial esterases and lipases proposed included only eight families [1], whereas recently, the 19th family was reported with a family XIX lipase from Stenotrophomonas maltophilia Psi-1 [7]. All esterases and lipases contain an $\alpha / \beta$ hydrolase fold [8]. However, diversity of the enzymes is variegated, dependent on their sequence identity and biochemical properties. 
Bacterial esterase and lipase sources have been expanded using metagenomes. A metagenome refers to the collective genomes of individual microorganisms in an environment without cultured microflora [9]. Microbial DNA has been directly extracted from sediments [10]. Metagenomes have also been called environmental DNA [11,12]. Metagenomics offers great advantages in biotechnology due to wider gene sources including unculturable microorganisms. Recently, it has been suggested that metagenomics is a powerful tool to obtain lipases for biocatalysts [13]. In practice, many types of esterases and lipases have been cloned from various ecosystems, such as lotus pond sludge [14], hypersaline lakes [15], mangrove sediments [16], paper mill wastewater sediments [17,18], soil [19-23], frozen soil [24], rumen [25], compost [26,27], and anaerobic ecosystems, such as rumens of dairy cows, large intestines of horses, freshwater sediments, and forest topsoils [28], and their properties have been extensively investigated and improved.

In our previous study, metagenomes were constructed from mud flats contaminated by oil spills, esterase and lipase clones were isolated from the metagenomic library, and the molecular properties of family IV Est3K and family I.3 Lip3K were reported [29]. During further analysis of the library, two novel positive clones were identified with different structures and properties from the two esterases.

In this paper, analyses of the two positive clones from the library and the molecular characteristics of two novel genes coding CzcO-containing family IV Est2L and family $\mathrm{V}$ Est4L with broad substrate specificity are described in detail. $\mathrm{CzcO}$ is associated with the cation diffusion facilitator $\mathrm{CzcD}$, which is related to efflux $\mathrm{Zn}^{2+}, \mathrm{Co}^{2+}$, and $\mathrm{Cd}^{2+}[30,31]$. The CzcO-containing family IV esterase was matched in the gene database; however, no information about its molecular characterization is available to date. Est4L has a low similarity to other Family V esterases whose molecular properties have been reported. Therefore, this work provides novel information about natural fusion esterase and diverse substrate specificity.

\section{Materials and Methods}

\subsection{Materials}

The compounds 5-bromo-4-chloro-3-indolyl- $\beta$-D-galactoside (X-gal) and isopropylthio$\beta$-D-galactoside (IPTG) were purchased from Bioneer (Daejeon, Korea). Artificial substrates ( $p$-nitrophenyl esters, $C_{2} \sim C_{16}$ ), enantiomers $[(R)$ - and $(S)$-methyl-3-hydroxy-2methylpropionate], glyceryl esters (glyceryl tributyrate glyceryl trioctanoate, and glyceryl trioleate), oils (fish oil and olive oil), acetylthiocholine iodide (ACTI), S-butyrylthiocholine iodide (BTCI)), and 5,5'-dithiobis(2-nitrobenzoic acid) (DTNB) were purchased from Sigma(St. Louis, MO, USA). HiPrep 16/60 Sephacryl S-200 HR, HiTrap-Q HP (5 mL), Hi-TrapSP, t-butyl HIC (1 mL), and multi-modal MMC $(1 \mathrm{~mL})$ columns were obtained from GE Healthcare (Uppsala, Sweden). High-Q (5 mL), High-S (5 mL), and CHT-II (5 mL) columns were obtained from Bio-Rad (Hercules, CA, USA).

\subsection{Two Esterase-Positive Clones from the Oil-Polluted Mud Flat Metagenome Library}

The metagenome library was constructed using DNA isolated from the oil-polluted mudflat, and esterase-positive clones from plasmid transformants using pUC19 as a cloning vector were screened on LB agar plates containing ampicillin $(50 \mu \mathrm{g} / \mathrm{mL})$ and 1\% glyceryl tributyrate. Seven of the esterase-positive clones had been selected in a previous study, including SKE2 and SKE4 [29]. In this study, we analyzed two esterase-positive clones: Escherichia coli DH5 $\alpha$ SKE2 and SKE4.

\subsection{Sequence Analysis and Phylogenetic Tree}

Nucleotide sequences of the esterase-positive clones were determined using Solgent (Daejeon, Korea). Amino acid sequences and conserved regions were analyzed using BLASTp of NCBI (http:/ / www.ncbi.nlm.nih.gov, accessed on 9 September 2020). The putative signal peptide was predicted using SignalP 5.0 in CBS (http://www.cbs.dtu. $\mathrm{dk} /$ services/SignalP/, accessed on 9 September 2020). Molecular mass and PI were 
analyzed and multiple sequence alignments were performed using the Clustal $\mathrm{W}$ method in DNA/MAN (Lynnon Biosoft, version 4.11, Quebec City, QC, Canada). The phylogenetic tree with other esterase/lipase families was constructed with MEGA version X [32,33] using the neighbor-joining method.

\subsection{Enzyme Assays}

Esterase activity was measured by observing the amount of $p$-nitrophenol produced from the reaction of esterase and $p$-nitrophenyl ester. Reaction mixtures containing esterase and $1 \mathrm{mM} p$-nitrophenyl butyrate in $50 \mathrm{mM}$ Tris- $\mathrm{HCl}$ ( $\mathrm{pH}$ 8.0) buffer were monitored continuously for $2 \mathrm{~min}$ at $25^{\circ} \mathrm{C}$ at $400 \mathrm{~nm}$ using the kinetic mode of a spectrophotometer (Optizen, K-Lab, Daejon, Korea). One unit of enzyme was defined as the amount releasing $1 \mu \mathrm{mol}$ of $p$-nitrophenol per minute by using a molar extinction coefficient of $16,400 / \mathrm{M} / \mathrm{cm}$ at $\mathrm{pH}$ 8.0. Acetylcholinesterase (AChE) and butyrylcholinesterase (BChE) activities were measured using ATCI and BTCI, respectively, as described previously [34]. Enzymes were combined with $0.5 \mathrm{mM}$ substrate and $0.5 \mathrm{mM}$ DTNB in $50 \mathrm{mM}$ sodium phosphate (pH 7.5) buffer, and were monitored continuously at $25^{\circ} \mathrm{C} 412 \mathrm{~nm}$ for $10 \mathrm{~min}$ in the kinetic mode. All assays in this study were carried out with independent duplicate or triplicate experiments.

\subsection{Preparation of Crude Enzymes}

After the detection of esterase activity on the LB agar plate containing X-gal and IPTG, each clone (SKE2 or SKE4) was cultured in $200 \mathrm{~mL}$ of broth at $37^{\circ} \mathrm{C}$ and $200 \mathrm{rpm}$ for $15 \mathrm{~h}$ with $1 \%$ seed. The cultured medium was centrifuged at $4{ }^{\circ} \mathrm{C}$ and $6000 \times g$ for $15 \mathrm{~min}$, and the collected pellet was washed two times by resuspending in $20 \mathrm{~mL}$ of $20 \mathrm{mM}$ Tris- $\mathrm{HCl}(\mathrm{pH} 8.0)$ buffer and centrifuging for $5 \mathrm{~min}$ at $4{ }^{\circ} \mathrm{C}$ and $6000 \times g$. The pellet was homogenized in $5 \mathrm{~mL}$ of $20 \mathrm{mM}$ Tris- $\mathrm{HCl}$ (pH 8.0), and sonication was performed using a microtip for $1 \mathrm{~min}$ under the pulse setting $1 \mathrm{~s} / 1 \mathrm{~s}$ with an amplitude of $38 \%$, repeated three times. After centrifugation at $4{ }^{\circ} \mathrm{C}$ and $6000 \times g$ for $5 \mathrm{~min}$, the supernatant was collected to obtain the crude enzyme.

\subsection{Isolation of the Enzymes}

Each crude enzyme was dialyzed for $2 \mathrm{~h}$ against the same buffer at $4{ }^{\circ} \mathrm{C}$, inverted three times at $30 \mathrm{~min}$ intervals, and was then loaded into the HiTrap-Q column. A linear gradient of a low (20 mM Tris- $\mathrm{HCl}, \mathrm{pH} 8.0)$ and a high buffer $(20 \mathrm{mM}$ Tris- $\mathrm{HCl}$ containing $1 \mathrm{M} \mathrm{NaCl}, \mathrm{pH} 8.0$ ) was applied at a flow rate of $1.0 \mathrm{~mL} / \mathrm{min}$ for $1 \mathrm{~h}$ using the Biologic LP System (Bio-Rad). Enzyme activities of the fractions were assayed and active fractions were pooled. The eluted HiTrap-Q pool was loaded into the Sephacryl S-200 HR column for size exclusion chromatography to purify and to determine the molecular mass of the intact enzyme. Immunoglobulin $\mathrm{G}$ (IgG) and bovine serum albumin (BSA) were used for molecular mass standard markers (166 and $66.4 \mathrm{kDa}$, respectively). Elution was performed by flowing $50 \mathrm{mM}$ sodium phosphate $(\mathrm{pH} 7.0)$ containing $0.15 \mathrm{M} \mathrm{NaCl}$ at a flow rate of $0.8 \mathrm{~mL} / \mathrm{min}$. When Sephacryl S-200 HR was used as the first column, the crude sample was dialyzed with the same buffer. The purified enzyme was analyzed with SDS-PAGE using an $11.5 \%$ polyacrylamide gel [35]. Protein concentration was determined by the Bradford assay method using BSA as a standard [36].

\subsection{Characterization of the Enzymes}

To determine the optimum temperature, $50 \mathrm{mM}$ Tris- $\mathrm{HCl}$ ( $\mathrm{pH}$ 8.0) buffer was preheated to test temperatures, at which the substrate and the enzyme were added. $\mathrm{Ab}$ sorbance was measured using a spectrophotometer. To measure thermostability, the enzyme was heated at $30,40,50$, and $60^{\circ} \mathrm{C}$ for $0,5,10,20,30$, and $60 \mathrm{~min}$ prior to substrate addition, and enzyme activity was then measured at indicated times using the standard assay condition. The half-life at each temperature was determined graphically by calculating the time showing $50 \%$ of the relative activity. To confirm the optimum $\mathrm{pH}$, enzyme activities were measured using $50 \mathrm{mM}$ Universal buffer (boric acid/citric acid/trisodium 
orthophosphate) for $\mathrm{pH}$ from 6.0 to 12.0. The molar absorption coefficients of each $\mathrm{pH}$ were used as described in a previous study [29].

Substrate specificity was analyzed using $\mathrm{p}-\mathrm{NP}$ esters, such as p-NP acetate (C2), p-NP butyrate (C4), p-NP caproate (C6), p-NP octanoate (C8), p-NP decanoate (C10), p-NP laurate (C12), p-NP myristate (C14), and p-NP palmitate (C16). Kinetic experiments were performed using five different substrate concentrations: $0.1,0.2,0.5,1.0$, and $2.0 \mathrm{mM}$ of C4. The $\mathrm{K}_{\mathrm{m}}$ and $\mathrm{V}_{\max }$ values were determined by a Lineweaver-Burk plot using Excel 2016 software.

The ion effect on enzyme activity was investigated by adding $\mathrm{K}^{+}, \mathrm{Na}^{+}, \mathrm{Mg}^{2+}, \mathrm{Mn}^{2+}$, $\mathrm{Ca}^{2+}, \mathrm{Cu}^{2+}, \mathrm{Co}^{2+}, \mathrm{Ba}^{2+}, \mathrm{Fe}^{2+}$, and $\mathrm{Zn}^{2+}$ ions at 2 and $5 \mathrm{mM}$ concentrations, after dialysis of the enzyme sample against $50 \mathrm{mM}$ Tris- $\mathrm{HCl}(\mathrm{pH}$ 8.0) for $6 \mathrm{~h}$ with two buffer changes. The inhibitor effects of EDTA and PMSF were analyzed at $1 \mathrm{mM}$ concentration. Enzyme stability against organic solvents was measured using methanol, isopropanol, and acetonitrile at concentrations of $5 \%$ and $30 \%$. Stability against surfactants was measured by adding sodium dodecyl sulfate (SDS) and Triton X-100 at concentrations of $1 \%$. Because $p$-nitrophenyl butyrate as the substrate was dissolved in isopropanol, $1 \%$ isopropanol was included in the control.

The lipid hydrolysis activity of the enzyme was confirmed using a pH shift assay [37]. In $20 \mathrm{mM}$ Tris- $\mathrm{HCl}$ ( $\mathrm{pH} 8.0$ ), oils (fish oil and olive oil) and glyceryl triesters (glyceryl tributyrate glyceryl trioctanoate, and glyceryl trioleate) were added at a concentration of $1 \%$, and then $0.1 \%$ phenol red was added. Absorbance was measured using the kinetic mode of a spectrophotometer at $25^{\circ} \mathrm{C}$ and $560 \mathrm{~nm}$ for 180 min every 30 min to determine the amount of substrate remaining. To confirm the enantioselectivity of the enzyme, (R)-methyl-3-hydroxy-2-methyl-propionate and (S)-methyl-3-hydroxy-methyl-propionate were added at a concentration of $1 \%$ as a substrate [29].

\section{Results}

\subsection{Sequence Analyses and Multiple Alignments of Est2L and Est4L}

As a result of the analysis of metagenomic DNA extracted from oil contaminants, two open reading frames (ORFs) were found in the insert DNAs from SKE2 and SKE4 and were named Est2L and Est4L, respectively. Est2L and Est4L were analyzed to be proteins with masses of 92,478 and 30,065 Da and consisting of 839 and 267 amino acids respectively. Interestingly, the initiation codon for Est4L was GTG instead of ATG with a Shine-Dalgarno sequence of $5^{\prime}$ AGGA GTTCAC at the upstream. Their theoretical $\mathrm{pI}$ values were 8.51 and 6.41, respectively. Est2L and Est $4 \mathrm{~L}$ were predicted to correspond to lipolytic families IV and $V$ respectively from a phylogenetic tree constructed by Mega $X$ (Figure 1), and neither enzyme had a signal peptide, suggesting they were intracellular esterases. Sequences of Est2L and Est4L were deposited at GenBank under accession numbers MT989338 and MT989339 respectively.

As a result of BLASTp, the amino acid sequence of Est2L was most closely identified $(99.17 \%)$ with that of an alpha/beta hydrolase fold domain-containing protein of Pseudomonas protegens (WP_041119155). Est2L was analyzed to have two protein domains: a domain comprising 10-419 amino acid residues matched the $\mathrm{CzcO}$ superfamily, which is associated with $\mathrm{CzcD}$, a cationic diffusion promoter, and a domain comprising 573-811 amino acid residues matched the acetylesterase superfamily (Figure S1a in Supplementary). Est4L was identified as an alpha/beta fold hydrolase of unclassified Pseudomonas (WP_177019666.1) with the highest confidence (100\%), and was matched to the $\alpha / \beta$ hydrolase_1 superfamily (Figure S1b in Supplementary). These genes have been annotated previously; however, their enzymatic properties have not been reported prior to this study.

A multiple sequence alignment (MSA) of the $\mathrm{CzcO}$ domain was performed with other matched gene sequences, because no $\mathrm{CzcO}$ domain had been characterized. The MSA of the CzcO domain showed several conserved regions such as GXGXXG (24 29), GXXW (55 58), ATG (148 150) VXVXGXXXS (186 194), and TGF (317 319) (Figure S2a). The MSA of Est2L compared to other lipolytic family IV enzymes revealed that Est2L contains conserved 
regions, such as HGG motif (595 597), DYR motif (626 628), GXXXG motif (663 667), GXPP

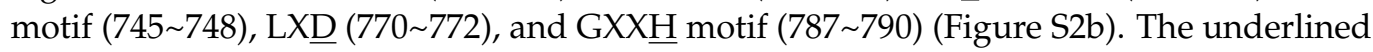
residues $\mathrm{S}, \mathrm{D}$, and $\mathrm{H}$, which are known to form a catalytic triad in the alpha/beta hydrolase superfamily [1], were identified in Est2L. The MSA of Est4L compared to other lipolytic family $\mathrm{V}$ enzymes showed that Est4L contains several conserved regions, such as HGXGX (26 30), GXS (57 59), GXSMGG (91 96), and PTL (203 205) (Figure S2c). Est4L also had a catalytic triad, i.e., S, underlined in GXSMGG, D212, and H239.

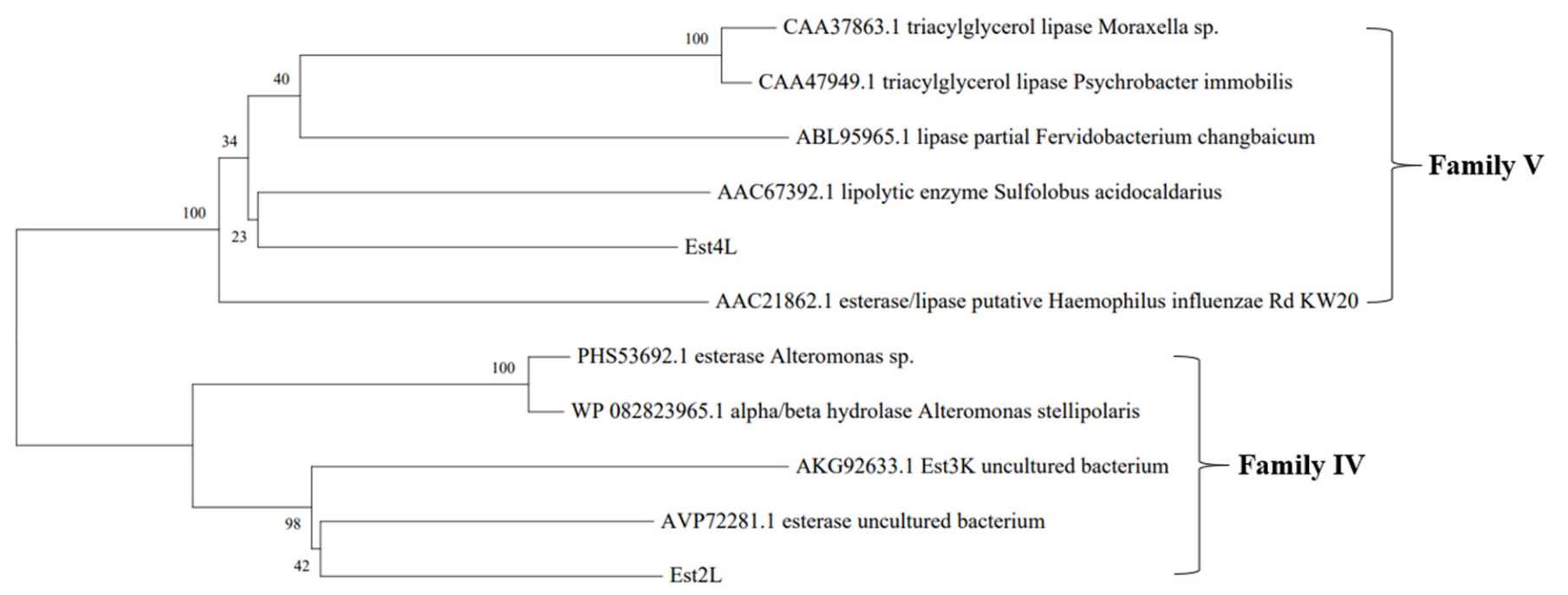

Figure 1. A phylogenetic tree of Est2L and Est4L. The tree is drawn to scale, and branch lengths are shown in the same units as those of the evolutionary distances used to infer the phylogenetic tree, using 12 amino acid sequences. Evolutionary analyses were conducted in MEGA X using the neighbor-joining method.

\subsection{Isolation of Est2L and Est $4 \mathrm{~L}$}

Est2L and Est4L were not bound to HiTrap-Q under the condition of $20 \mathrm{mM}$ Tris/ $\mathrm{HCl}$, $\mathrm{pH}$ 8.0, and a small number of enzymes were eluted at the gradient (Figure 2). In the control experiment using E. coli DH5 $\alpha$ (pUC19), endogenous esterase activity was negligible compared to the two positive clones (Figure 2). After HiTrap-Q chromatography, the purification folds of Est2L and Est4L in the unbound fractions were 2.56 and 1.70 and had yields of $22.6 \%$ and $12.5 \%$, respectively (Table 1). Using the pools, the two enzymes were separated further using Sephacryl S-200 HR for the purpose of purification and estimation of the molecular masses of intact enzymes. Enzyme activities in the extracts were low, and unfortunately, activities drastically decreased during the dialysis and column development stages. Thus, Est2L activity was too low to be detected, and the purification fold of Est4L decreased considerably to 0.73 (Table 1). As an alternative, Est2L was separated using Sephacryl S-200 HR as the first column, and the purification fold was 5.36 (Table 1). CHT-II, HIC, HiTrap-SP, High-S, and MMC chromatographies were not effective in the recovery of Est2L or Est4L.

In SDS-PAGE analysis with $11.5 \%$ polyacrylamide gels, protein bands in the HiTrapQ and Sephacryl S-200 HR pools were not homogeneous; however, predicted bands corresponding to the molecular masses of Est2L and Est4L were observed at 100 and $31 \mathrm{kDa}$, respectively (Figure 3). Because homogeneous and active enzymes were not obtained, these fractions were used for further study.

The molecular masses of intact Est2L and Est4L enzymes were determined to be $183.2 \pm 23.6$ and $125.4 \pm 8.65 \mathrm{kDa}$, respectively, according to the elution volumes of Sephacryl S-200 HR chromatographies (Table 2). These results suggest that Est2L and Est4L exist in a dimer and a tetramer form respectively, by comparing their respective molecular masses of 92.5 and $30.1 \mathrm{kDa}$. 


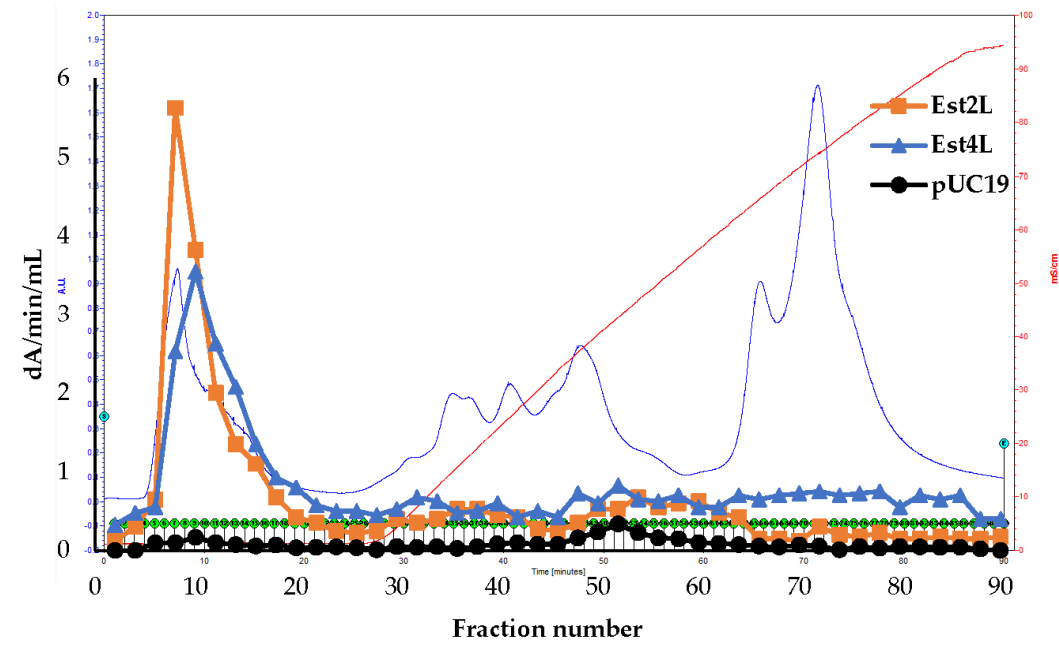

Figure 2. HiTrap-Q chromatograms of crude extracts of $E$. coli $\mathrm{DH} 5 \alpha$ strains harboring a plasmid pUC19 as a control and recombinant plasmids SKE2 and SKE4 as sources for esterases Est2L and Est4L, respectively. The different volume of each fraction was appropriately measured for the esterase activity. Activity was calculated as $\mathrm{dA} / \mathrm{min}$, then divided by the volume of the fraction, and finally expressed as $\mathrm{dA} / \mathrm{min} / \mathrm{mL}$ on the $Y$-axis. The chromatogram of UV absorbance (blue line) at $280 \mathrm{~nm}$ (A.U.) of Est2L was added along with conductivity (red line) $(\mathrm{mS} / \mathrm{cm})$. The UV chromatograms of Est4L and pUC19 samples were similar to that of Est2L. Protein concentrations of the highest active fractions of Est2L, Est4L, and pUC19 samples were 1.8, 1.4, and $1.6 \mathrm{mg} / \mathrm{mL}$, respectively.

Table 1. Specific activities and yields of Est2L and Est4L during separation.

\begin{tabular}{ccccc}
\hline \multirow{2}{*}{ Enzyme } & Preparation & Specific Activity (U/mg) & $\begin{array}{c}\text { Purification } \\
\text { (Fold) }\end{array}$ & Yield (\%) \\
\hline \multirow{3}{*}{ Est2L } & Crude extract & 0.043 & 1.00 & 100 \\
& HiTrap-Q & 0.11 & 2.56 & 22.6 \\
\cline { 2 - 5 } & Crude extract & 0.041 & 1.00 & 100 \\
& Sephacryl S-200 & 0.22 & 5.36 & 9.45 \\
\hline \multirow{3}{*}{ Est4L } & Crude extract & 0.037 & 1.00 & 100 \\
& HiTrap-Q & 0.063 & 1.70 & 12.5 \\
& Sephacryl S-200 & 0.027 & 0.73 & 2.25 \\
\hline
\end{tabular}
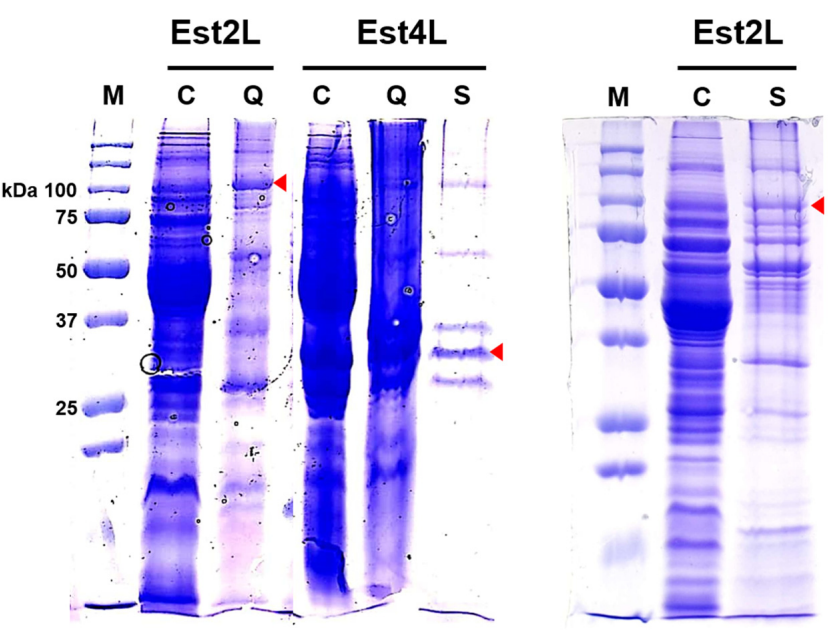

Figure 3. SDS-PAGE of Est2L and Est4L. M, size markers; C, crude extract; Q, HiTrap-Q pool; S, Sephacryl S-200 HR pool. Arrows represent the predicted protein bands corresponding to the molecular masses of Est2L and Est4L. 
Table 2. Molecular masses of native Est2L and Est4L determined with Sephacryl S-200.

\begin{tabular}{cccc}
\hline Protein & Fraction Volume $(\mathbf{m L})$ & Molecular Mass $(\mathbf{k D a})$ & $\log$ Mw \\
\hline Est2L & 37.5 & $183.2 \pm 23.6$ & 2.26 \\
\hline Est4L & 43.6 & $125.4 \pm 8.65$ & 2.10 \\
\hline IgG & 39 & 166 & 2.22 \\
BSA & 54 & 66.4 & 1.82
\end{tabular}

The means \pm SEs were calculated with duplicate and triplicate experiments for Est2L and Est4L respectively. $\operatorname{IgG}$, immunoglobulin G; BSA, bovine serum albumin.

\subsection{Propeties of Est2L and Est $4 \mathrm{~L}$}

Est2L showed the highest activity at $60^{\circ} \mathrm{C}$ and maintained a meaningful level (i.e., $76.2 \%$ ) of its activity even at $80{ }^{\circ} \mathrm{C}$ (Figure 4a). Est4L showed the highest activity at $40-50{ }^{\circ} \mathrm{C}$, and its activity did not noticeably increase between $30{ }^{\circ} \mathrm{C}$ and $60{ }^{\circ} \mathrm{C}$, i.e., it remained at $86.9 \sim 93.6 \%$ of the maximum activity, as opposed to Est2L, whose activity increased significantly by 2.58 times at $60^{\circ} \mathrm{C}$ compared to $30^{\circ} \mathrm{C}$ (Figure 4b). Both Est2L and Est4L showed optimal activities at $\mathrm{pH} 10$, indicating that they are alkaline esterases (Figure 5). In terms of thermal stability, Est2L had a half-life of $22.9 \mathrm{~min}$ at $50{ }^{\circ} \mathrm{C}$; however, its half-life rapidly decreased to $4.3 \mathrm{~min}$ at $60^{\circ} \mathrm{C}$ (Figure 6a). Est4L showed half-lives of 13.6 and $3.5 \mathrm{~min}$ at $40{ }^{\circ} \mathrm{C}$ and $50^{\circ} \mathrm{C}$, respectively (Figure $6 \mathrm{~b}$ ). Therefore, it was concluded that Est $2 \mathrm{~L}$ was 6.54 times more stable than Est $4 \mathrm{~L}$ at $50{ }^{\circ} \mathrm{C}$ based on their respective half-lives.

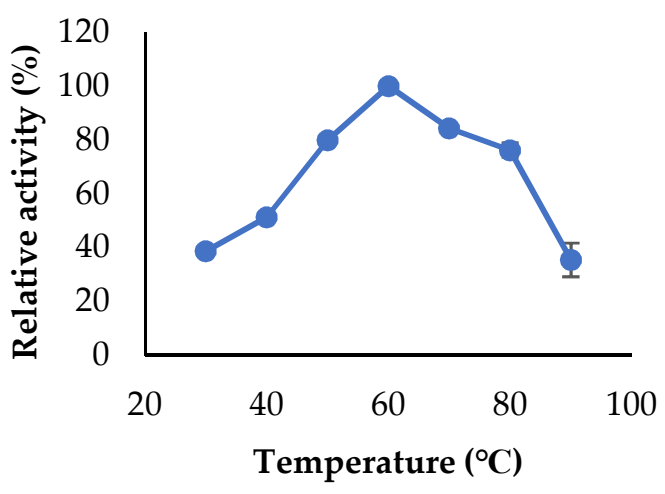

(a)

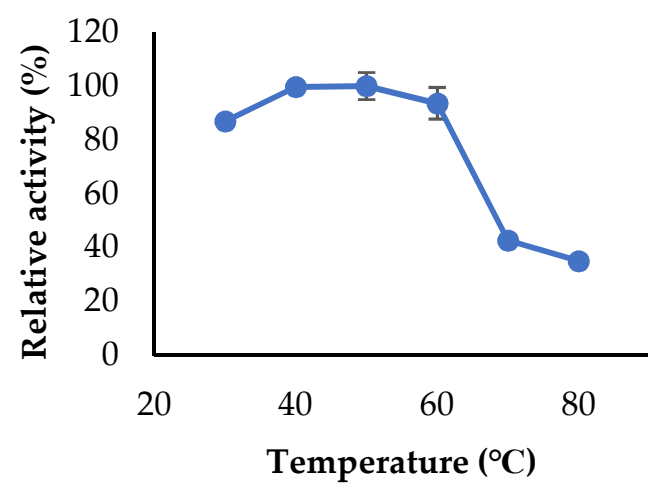

(b)

Figure 4. Optimum temperatures of Est2L (a) and Est4L (b). Enzyme activities were measured by a continuous method at each designated temperature.

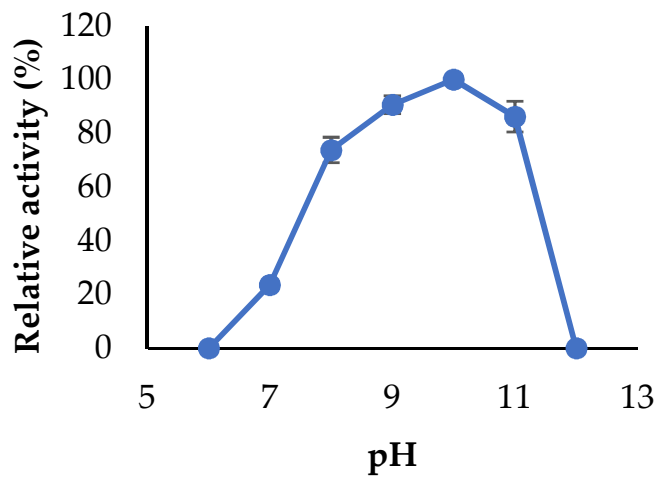

(a)

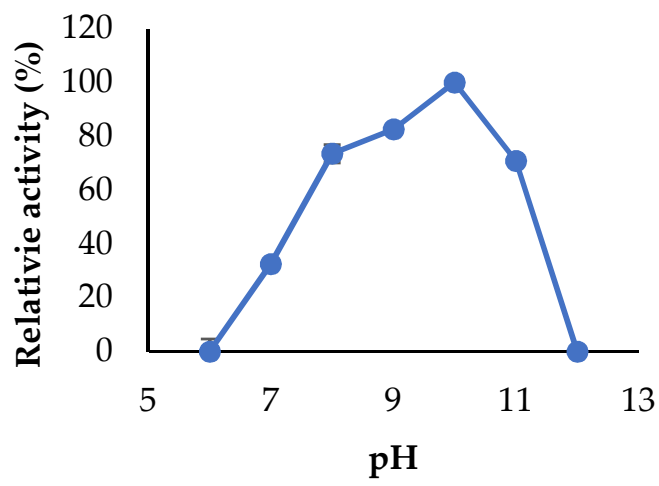

(b)

Figure 5. Optimum pH of Est2L (a) and Est4L (b). Enzyme activities were measured by a continuous method at each designated $\mathrm{pH}$. 


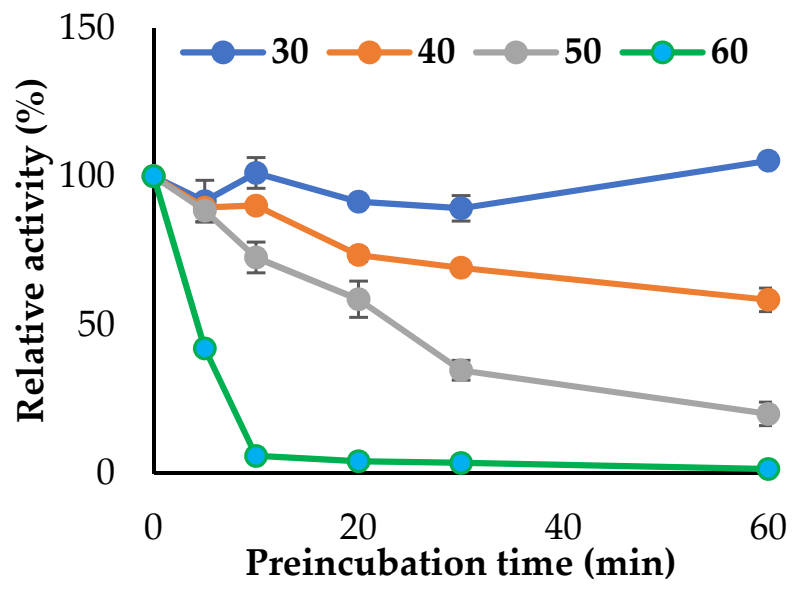

(a)

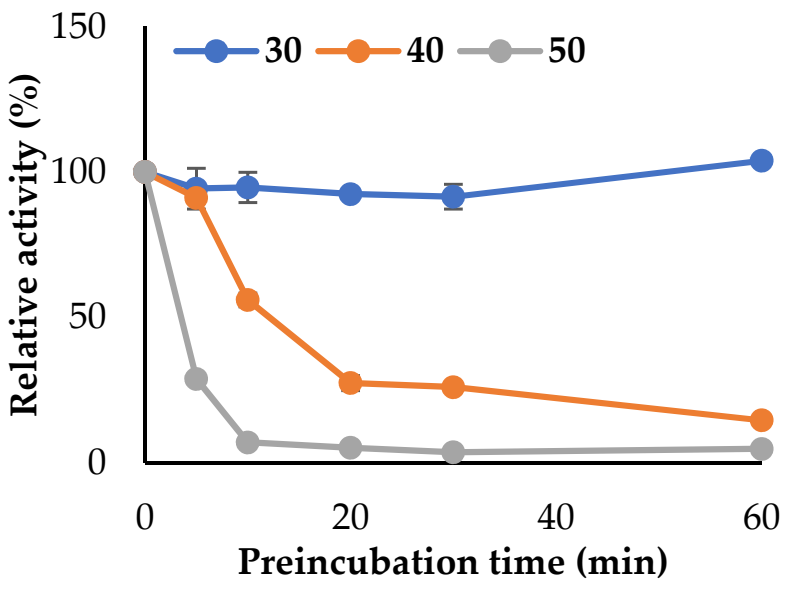

(b)

Figure 6. Thermal stabilities of Est2L (a) and Est4L (b). Enzyme activities were measured by a continuous method after preincubation of enzyme at each designated time.

Regarding substrate specificities for p-NP esters, Est2L showed the highest activity with C2, followed by C4 (73.5\%) and C6 (46.2\%) (Figure 7a). It did not show any significant activity with p-NP ester substrates with more than 8 carbon chains, and showed the typical substrate specificity of acetylesterase. However, Est4L showed the highest reactivity with C10, followed by C2 (95.2\%) and C4 (94.6\%) to a similar extent (Figure 7b). Moreover, Est4L showed more than $50 \%$ of relative activities for C8 (73.6\%), C12 (55.6\%), and C6 (50.6\%). The activities for $\mathrm{C} 14$ and $\mathrm{C} 16$ significantly decreased to $13.3 \%$ and $2.8 \%$, respectively. On the other hand, Est2L showed BTCI and ATCI hydrolyzing activities of $13.3 \%$ and $25.4 \%$ respectively, which were higher than those of Est4L (Figure 7a,b).

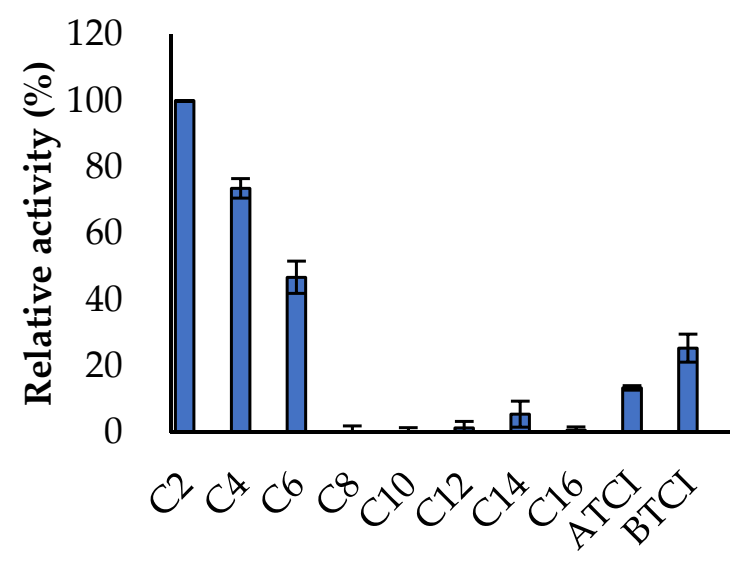

(a)

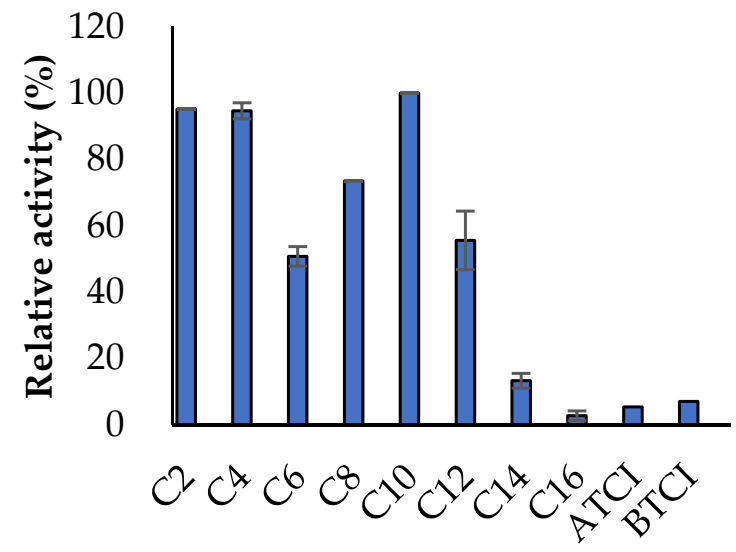

(b)

Figure 7. Substrate specificities of Est2L (a) and Est4L (b). Enzyme activities with C2 to C16 were measured using $1 \mathrm{mM}$ p-nitrophenyl esters in $50 \mathrm{mM}$ Tris- $\mathrm{HCl}$ ( $\mathrm{pH} 8.0$ ), and those of acetylcholinesterase (AChE) and butyrylcholinesterase (BChE) were measured using $0.5 \mathrm{mM}$ ATCI and BTCI respectively, with $0.5 \mathrm{mM}$ DTNB in $50 \mathrm{mM}$ sodium phosphate (pH 7.5) buffer.

In kinetic studies analyzed by the Lineweaver-Burk plot, Est2L had a $\mathrm{K}_{\mathrm{m}}$ value of $0.67 \mathrm{mM}$ for C4, and Est4L had a higher affinity for the substrate at $0.10 \mathrm{mM}$ (Figure 8). The $V_{\max }$ values of Est2L and Est $4 \mathrm{~L}$ were 0.072 and $0.036 \mathrm{U} / \mathrm{mg}$, respectively. 


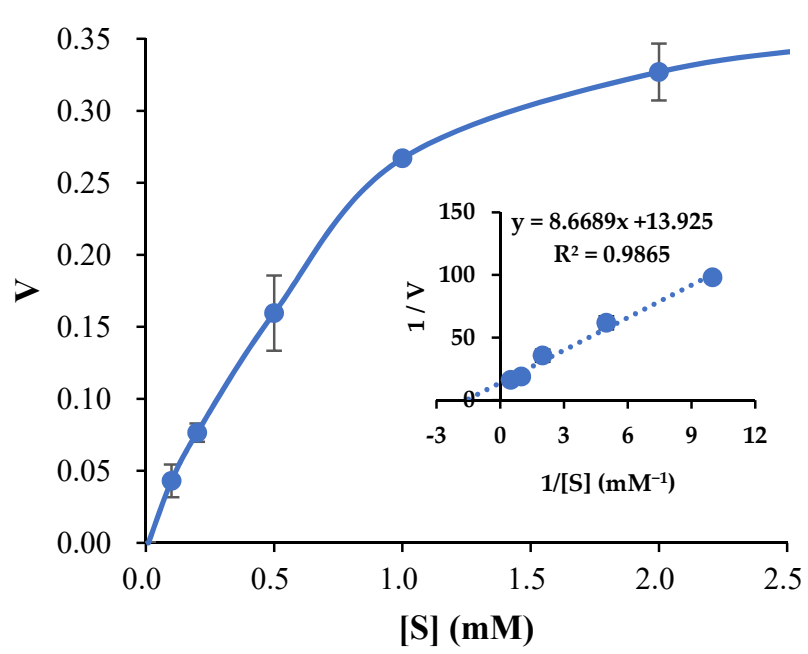

(a)

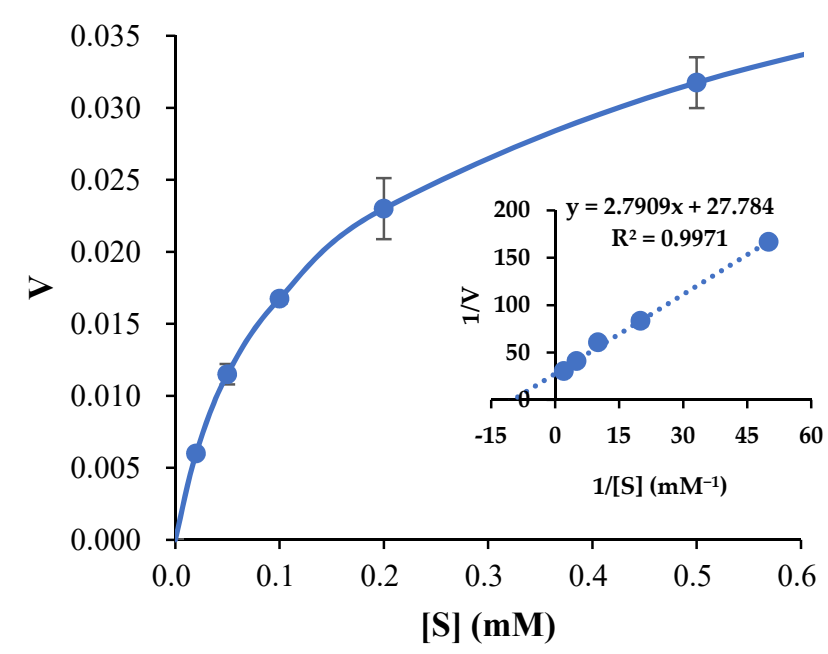

(b)

Figure 8. Michaelis-Menten and Lineweaver-Burk plots of Est2L (a) and Est4L (b) for C4. Experiments were performed at five different substrate concentrations of $0.1,0.2,0.5,1.0$, and $2.0 \mathrm{mM}$ of $\mathrm{C} 4$.

Regarding stability with organic solvents, Est2L was stable at $5 \%$ and $30 \%$ of methanol; however, it was deactivated to $76 \%$ and $15.7 \%$ at $5 \%$ and $30 \%$ isopropanol respectively, and to $69.3 \%$ and $6.7 \%$ at $5 \%$ and $30 \%$ acetonitrile respectively (Figure $9 a$ ). Est $4 \mathrm{~L}$ was also stable up to $30 \%$ methanol and was activated to $128.6 \%$, and was activated to $132.4 \%$ at $5 \%$ isopropanol but inactivated to $6.9 \%$ at $30 \%$ isopropanol. Est $4 \mathrm{~L}$ was inactivated to $67 \%$ and $7.5 \%$ at $5 \%$ and $30 \%$ acetonitrile (Figure $9 \mathrm{~b}$ ). By adding detergents, Est2L and Est $4 \mathrm{~L}$ were significantly inactivated to less than $10 \%$ at $1 \%$ SDS, but neither were inactivated at $1 \%$ Triton X-100, instead being activated to $124 \%$ and $119.8 \%$ respectively (Figure $9 a, b)$. In addition, phenylmethylsulfonyl fluoride (PMSF) inhibited Est2L by $73.0 \%$ at $1 \mathrm{mM}$, but had little effect on Est4L, which maintained $88.9 \%$ of its activity. However, the inhibition of Est4L by PMSF increased at a higher concentration $(10 \mathrm{mM})$ and became nearly complete with preincubation of Est4L and PMSF for $30 \mathrm{~min}$.

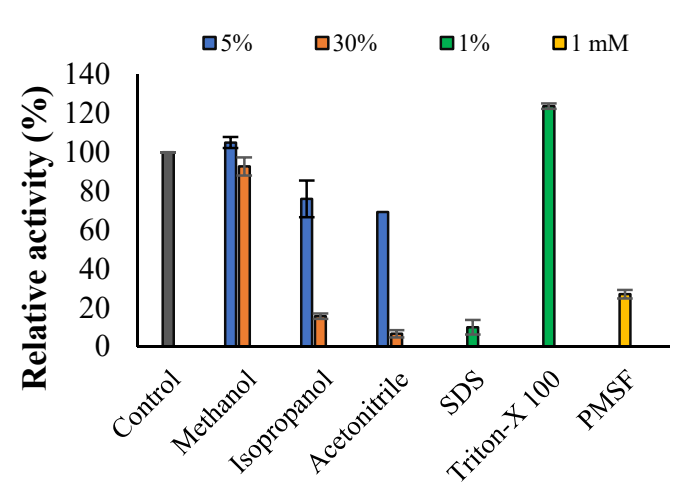

(a)

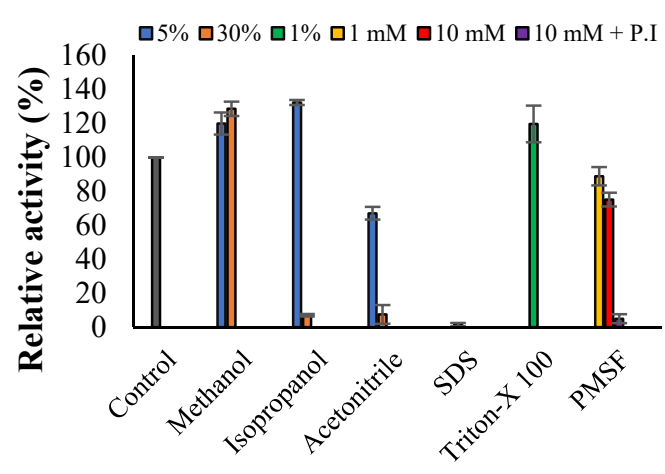

(b)

Figure 9. Effects of organic solvents, detergents, and PMSF on enzyme activities of Est2L (a) and Est4L (b). P.I., preincubated for $30 \mathrm{~min}$.

Regarding the effects of metal ions on enzyme activities, Est2L was activated to $139.8 \%$, $130.4 \%, 118.6 \%$, and $117.3 \%$ by $5 \mathrm{mM} \mathrm{Fe}^{2+}, \mathrm{Mn}^{2+}, \mathrm{Mg}^{2+}$, and $\mathrm{Ca}^{2+}$ respectively, but inhibited to $52.4 \%$ by $5 \mathrm{mM} \mathrm{Cu}^{2+}$ (Figure 10a). On the other hand, Est4L was not activated by the metal ions tested, but was greatly inhibited to $7.5 \%$ and $29.8 \%$ by $5 \mathrm{mM} \mathrm{Cu}^{2+}$ and $\mathrm{Zn}^{2+}$, respectively, and moderately inhibited to $63.8 \%$ by $5 \mathrm{mM} \mathrm{Fe}^{2+}$ (Figure 10b). No noticeable 
effect was observed from other ions. Regarding the effect of $\mathrm{Co}^{2+}$, little effect on Est2L was observed below $10 \mathrm{mM} \mathrm{Co}^{2+}$, but inhibition was observed at $20 \mathrm{mM} \mathrm{Co}^{2+}$. In addition, $\mathrm{Zn}^{2+}$ showed little effect on Est2L activity, though it showed more significant effects at a $20 \mathrm{mM}$ concentration (Figure 10c). It is concluded that $\mathrm{Fe}^{2+}, \mathrm{Mn}^{2+}, \mathrm{Mg}^{2+}$, and $\mathrm{Ca}^{2+}$ activated Est2L, and $\mathrm{Cu}^{2+}$ inhibited Est2L and Est4L; however, $\mathrm{Zn}^{2+}$ inhibited only Est4L but not Est2L, suggesting that metal ions in group 1 did not significantly affect Est2L and Est4L activities, but those in groups 11 or 12 inhibited the two enzymes.

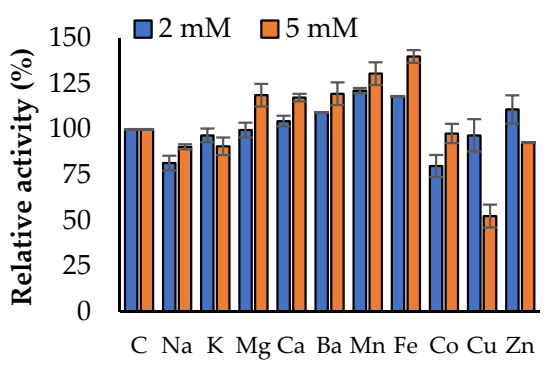

Ion

(a)

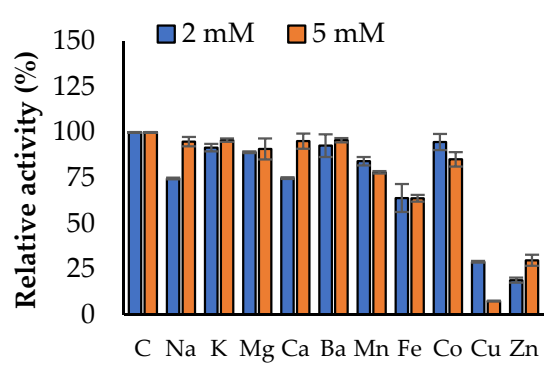

Ion

(b)

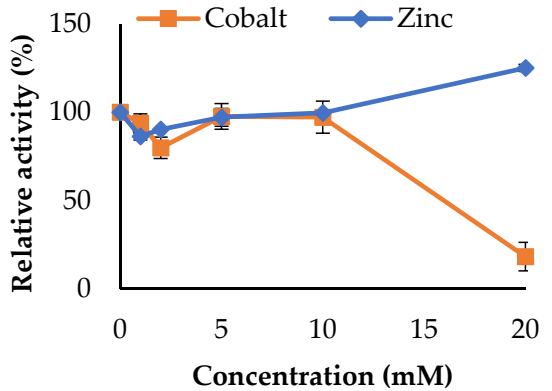

(c)

Figure 10. Effects of cations on the activities of Est2L (a) and Est4L (b) and of $\mathrm{Co}^{2+}$ and $\mathrm{Zn}^{2+}$ ions on Est2L activity (c). Control is the enzyme activity in the absence of metal ions.

Ethylenediaminetetraacetic acid (EDTA) showed insignificant effects on Est2L and Est $4 \mathrm{~L}$, which retained relative activities of $96.6 \%$ and $88.6 \%$ respectively. To observe the effects of EDTA and metal ion combinations, EDTA was preincubated and then metal ions were added, or vice versa, for Est2L and Est4L. In the experiments, little difference was observed as a result of change of preincubation order, except that inhibition by EDTA $>\mathrm{Cu}^{2+}$ was greater than that by $\mathrm{Cu}^{2+}->$ EDTA and inhibition by the combination of EDTA and $\mathrm{Co}^{2+}$ was greater than those of isolated EDTA or $\mathrm{Co}^{2+}$ in Est2L (Figure 11). It is possible that the bindings of $\mathrm{Cu}^{2+}$ or $\mathrm{Co}^{2+}$ and EDTA to Est2L were more complex than to Est4L.

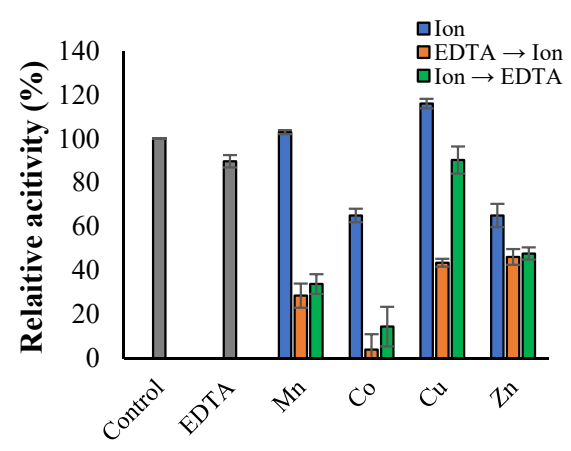

(a)

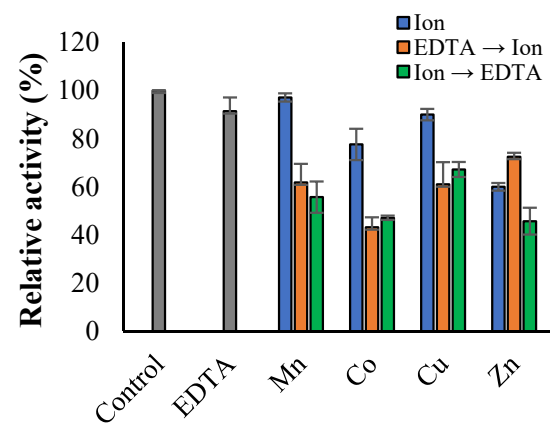

(b)

Figure 11. EDTA and metal ion effects on Est2L (a), and Est4L (b). The enzyme was preincubated with $1 \mathrm{mM}$ EDTA or metal ions for $30 \mathrm{~min}$, then $1 \mathrm{mM}$ metal ions or EDTA were added respectively, and finally enzyme activities were measured.

For the lipid hydrolysis activities, Est2L and Est4L hydrolyzed glyceryl tributyrate to $69.0 \%$ and $52.8 \%$ respectively, followed by trioctanoate to $77.9 \%$ and $71.9 \%$ respectively (Figure 12). It was confirmed that the hydrolyzing activities of fish oil, olive oil, and glyceryl trioleate by Est2L and Est4L were remarkably low. When based on glyceryl tributyrate as a substrate, Est4L showed a 25.1\% higher hydrolyzing activity than Est2L. 


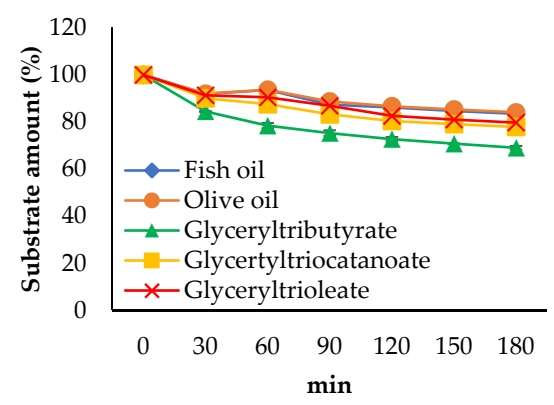

(a)

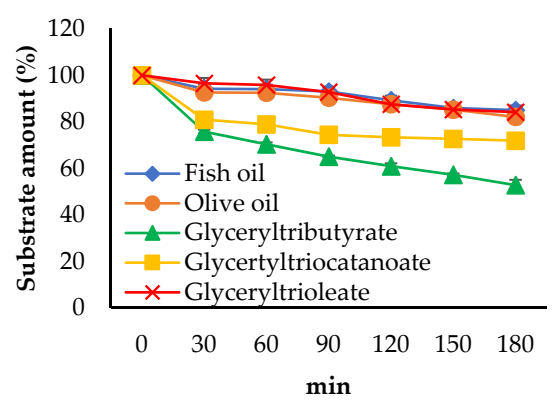

(b)

Figure 12. Lipid hydrolysis activities of Est2L (a) and Est4L (b), using a pH shift assay. Enzyme activities were measured at $1 \%$ substrates in $20 \mathrm{mM}$ Tris- $\mathrm{HCl}(\mathrm{pH} 8.0)$ by adding $0.1 \%$ phenol red.

Regarding enantioselectivity, Est2L showed no preference between R- and S-forms; however, Est4L showed a preference toward S-form at a low degree of $10.6 \%$, i.e., $89.6 \%$ and $79.3 \%$ of the residual substrate amounts in R- and S-form, respectively, under the condition (Figure 13).

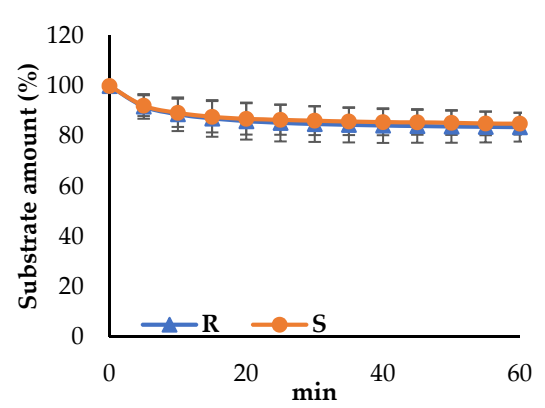

(a)

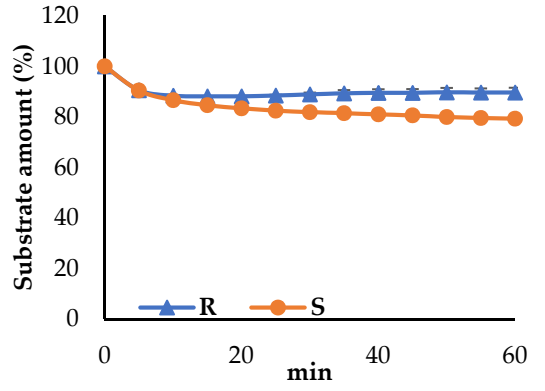

(b)

Figure 13. Enantioselectivities of Est2L (a) and Est4L (b). Enzyme activities were measured at 1\% (R)-methyl-3-hydroxy-2-methyl-propionate and (S)-methyl-3-hydroxy-methyl-propionate.

\section{Discussion}

In this study, two esterase genes, est $2 L$ and est $4 L$, were isolated from a metagenomic library; they encoded a family IV Est2L and a family V Est4L esterase, respectively. Two documented genes were similar or identical to the respective genes annotated from the genome sequences; however, the amino acid sequences of Est2L and Est4L were very dissimilar compared to those of the more than 20 family IV enzymes and less than 10 family $\mathrm{V}$ enzymes characterized to date, respectively. The highest values were $9.8 \%$ to $27.9 \%$ and $10.33 \%$ to $21.28 \%$ (Table 3 ) respectively. In addition, Est2L was a unique fusion type of protein, containing two domains of a $\mathrm{CzcO}$ and an acetylesterase domain (a member of family IV). Due to these points, Est2L was examined in this study, along with Est4L (a member of family V), although their activities and yields were low.

Bacterial family IV lipolytic enzymes show a strikingly high similarity to the mammalian hormone-sensitive lipase (HSL) [1]. Molecular masses of mammalian HSLs range from 84 to $130 \mathrm{kDa}$ [38] and are larger than bacterial HSLs (bHSL), which range from 31.2 to $41.2 \mathrm{kDa}$. Human HSL (hHSL) is composed of 786 amino acid residues. In general, HSL has two domains: the $\mathrm{N}$-terminal binding domain ( $\sim 315$ residues) and the C-terminal catalytic domain [38,39]; however, bHSL has a cap domain comprising 50-100 residues at the $\mathrm{N}$-terminus and the $\mathrm{C}$-terminal catalytic domain [39]. The $\mathrm{N}$-terminal binding domain mediates protein-protein interactions, specifically with adipocyte lipid binding protein [40], whereas the cap domain plays an important role in enzyme stability and specificity [41]. Interestingly, Est2L was much larger in molecular mass, i.e., 839 residues and $92.5 \mathrm{kDa}$, than other bHSL enzymes characterized to date. It was also larger than hHSL. The size difference resulted from the large $\mathrm{N}$-terminal domain (10-419 residues, $\mathrm{CzcO}$ superfamily) 
of Est2L. The role of $\mathrm{CzcO}$ has been poorly understood, with the exception of its role in enhancing the activity of $\mathrm{CzcD}$, which effluxes divalent cations such as $\mathrm{Zn}^{2+}, \mathrm{Co}^{2+}$, and $\mathrm{Cd}^{2+}[30,31]$, and reduces the accumulation of these cations in Ralstonia metallidurans CH34 by an unspecified mechanism [42]. Curiously, the $\mathrm{CzcO}$ domain was fused to the family IV bHSL domain of Est2L, notwithstanding that the two domains would not be closely related. To test the effects of divalent cations, changes in Est2L were analyzed at several concentrations of $\mathrm{Co}^{2+}$ and $\mathrm{Zn}^{2+}$; however, significant effects were not observed for $\mathrm{Co}^{2+}$ and $\mathrm{Zn}^{2+}$ except an inhibition at a high concentration of $\mathrm{Co}^{2+}$, although Est2L contains the domain $\mathrm{CzcD}$, which is related to efflux of $\mathrm{Zn}^{2+}, \mathrm{Co}^{2+}$, and $\mathrm{Cd}^{2+}$. It could be suggested that neither $\mathrm{Co}^{2+}$ or $\mathrm{Zn}^{2+}$ ions bind to the $\mathrm{CzcO}$ domain in order to stabilize the catalytic domain of Est2L, acting unlike an N-terminal binding domain in hHSL or a cap domain in bHSL. In addition, $\mathrm{CzcD}$ is different from the N-terminal transmembrane domain of LipA from Pseudomonas protegens Pf-5, which is short (22 amino acid residues) and contributes efficient folding, probably in order to act as an intramolecular chaperone [43].

On the other hand, an esterase EstO with OsmC (osmotically induced protein C) was identified in a marine bacterium Pseudoalteromonas arctica [44], and was characterized as part of a new family of carboxylesterase [45]. Recently, an esterase SLC6 with OsmC from sea sediment metagenome was characterized [46]. Interestingly, OsmC was located at the C-terminus of the proteins, unlike CzcO of Est2L. Furthermore, OsmC was composed of approximately 160 residues, much shorter than $\mathrm{CzcO}$ with approximately 400 residues.

Specific activities of Est2L $(0.043 \mathrm{U} / \mathrm{mg})$ and Est $4 \mathrm{~L}(0.037 \mathrm{U} / \mathrm{mg})$ in crude extracts were lower than that of Lip3K, which had the lowest specific activity $(0.25 \mathrm{U} / \mathrm{mg})$ found in our results previously reported [29]. Thus, it was difficult to separate homogeneous proteins with two or more column steps. Although several columns were used for purification by combinational sets, recovery and purification were not successful. Therefore, we investigated the enzymatic properties with partially purified enzymes. Considering the low specific activities, actual natural substrates of Est2L and Est4L should be investigated in further research.

Native Est2L was found to have dimeric forms similar to most other family IV enzymes (Table 3), although some were reported to have monomeric to tetrameric forms. EstE7 existed in various forms, including monomer, dimer, and aggregated forms with reversible oligomerization, of which the dimer form showed the highest activity [47]. Cest-2923 had dimer and tetramer forms at neutral and acidic $\mathrm{pH}$, respectively [48], and REst1 had monomer and trimer forms [49]. Little information is available about the native forms of family V enzymes (Table 3). Est4L was tetramer in form, whereas Est16 [50] and OpeH [51] were monomer in form, and $\mathrm{LacH}$ [52] was dimer in form.

Optimum temperatures of family IV enzymes were extremely diverse, ranging from $10.5{ }^{\circ} \mathrm{C}$ for E69 [53] to $95{ }^{\circ} \mathrm{C}$ for EstE1 [54], and that of Est2L (60 ${ }^{\circ} \mathrm{C}$ ) was higher than that of Est3K [29] and was located in the upper range (Table 3). The range of optimum temperatures of family $\mathrm{V}$ enzymes was relatively narrow from $35^{\circ} \mathrm{C}$ for $\mathrm{H} 8$ [55] to $78{ }^{\circ} \mathrm{C}$ for FCLip1 [56], and that of Est4L was in the center region (Table 3).

Est2L was found to be an intracellular enzyme without a signal peptide similar to most other HSL and family IV lipolytic enzymes [41], and Est4L was also an intracellular enzyme. Est2L showed a substrate preference for short pNP-esters, similar to many other family IV lipolytic enzymes, including Cest-2923 [48], Est22 [57], and EstA1 [58] (Table 3). Est4L preferred relatively long pNP-esters (especially C10), similar to FCLip1 [56], whereas most other family $\mathrm{V}$ enzymes prefer shorter pNP-esters (Table 3). Interestingly, Est2L hydrolyzed BTCI, which was used as a substrate for BChE, suggesting that Est2L has broad specificity to various types of esters, whereas Est4L efficiently hydrolyzed up to C12 without BChE activity, indicating that Est4L has broad substrate specificity to longer pNP esters. These properties make them highly attractive for industrial applications, especially for ester prodrugs, providing a basic strategy for masking functionalities of polar alcohol and carboxylic acid and improving permeabilities [4]. 
Table 3. Comparison of Est2L and Est4L with other esterases.

\begin{tabular}{|c|c|c|c|c|c|c|c|c|c|c|c|c|c|c|c|}
\hline \multirow{2}{*}{ Protein } & \multirow{2}{*}{ Accession } & \multirow{2}{*}{ Source } & \multirow{2}{*}{ Homology (\%) } & \multirow{2}{*}{ AA } & \multirow{2}{*}{ MW (kDa) } & \multirow{2}{*}{ Native Form } & \multirow{2}{*}{ Opt Temp. $\left({ }^{\circ} \mathrm{C}\right)$} & \multirow{2}{*}{ Opt. pH } & \multirow{2}{*}{ pNP Esters } & \multicolumn{3}{|c|}{ Solvent Stability (\%) } & \multicolumn{2}{|c|}{ Metal Ion } & \multirow{2}{*}{ Ref. } \\
\hline & & & & & & & & & & IPA & $\mathrm{MeOH}$ & $\mathrm{ACN}$ & Activating & Inhibiting & \\
\hline \multicolumn{16}{|l|}{ Family IV } \\
\hline Est2L * & MT989338 & Uncultured bacterium & 100 & 839 & 92.5 & Di & 60 & 10.0 & $\mathrm{C} 2$ & $15.7^{\mathrm{a}}$ & $92.7^{\mathrm{a}}$ & $6.67^{\mathrm{a}}$ & \multirow[t]{2}{*}{$\begin{array}{c}\mathrm{Mg}^{2+} \\
\mathrm{Mn}^{2+}, \mathrm{Fe}^{2+}\end{array}$} & $\mathrm{Cu}^{2+}$ & This study \\
\hline Est3K & AKG92633 & Uncultured bacterium & 19.90 & 299 & 32.4 & & 50 & 9 & $\mathrm{C} 4$ & $87.5^{\mathrm{a}}$ & $86.9^{\mathrm{a}}$ & $47.7^{\mathrm{a}}$ & & $\mathrm{Cu}^{2+}$ & [29] \\
\hline EstE7 & ABI18352 & Uncultured bacterium & 27.93 & 322 & 34.6 & $\mathrm{Di}$ & 40 & 5 & $\mathrm{C} 4$ & & & & \multirow{8}{*}{$\mathrm{Cd}^{2+}$} & & [47] \\
\hline Cest-2923 & CСC79999 & Lactobacillus plantarum & 9.75 & 282 & 31.2 & Di, Tetra & 30 & 7 & $\mathrm{C} 2$ & & & & & & [48] \\
\hline REst1 & FJ645062 & Rheinheimera sp. & 15.56 & 342 & 37.2 & Mono, Tri & 50 & 8 & $\mathrm{C} 4$ & & $0^{\text {a }}$ & & & $\mathrm{Mg}^{2+}, \mathrm{Hg}^{2+}$ & [49] \\
\hline E69 & AUD08548 & Erythrobacter seohaensis & 18.18 & 274 & 29.5 & & 10.5 & 6 & $\mathrm{C} 4$ & $0^{\mathrm{b}}$ & $28.8^{\mathrm{b}}$ & $35.0^{\mathrm{b}}$ & & & [53] \\
\hline EstE1 & AAW62260 & Uncultured archaeon & 19.85 & 311 & 33.7 & Di & 95 & 6 & C6 & & & & & & [54] \\
\hline Est22 & AFB82695 & Uncultured bacterium & 16.51 & 365 & 39 & Di & 40 & 7.5 & $\mathrm{C} 2$ & $40^{\mathrm{b}}$ & $120^{\mathrm{b}}$ & $0^{\mathrm{b}}$ & & $\begin{array}{l}\mathrm{Zn}^{2+}, \mathrm{Cu}^{2+} \\
\mathrm{Ni}^{2+}\end{array}$ & [57] \\
\hline EstA1 ** & PHS53692.1 & \multirow{2}{*}{$\begin{array}{l}\text { Alteromonas sp. } \\
\text { Pyrobaculum calidifontis } \\
\text { Alicyclobacillus } \\
\text { acidocaldarius }\end{array}$} & 18.97 & 379 & 41.2 & & 45 & 8 & $\mathrm{C} 2$ & $102^{\mathrm{b}}$ & $100^{\mathrm{b}}$ & $68^{\mathrm{b}}$ & & & {$[58]$} \\
\hline $\begin{array}{l}\text { PestE } \\
\text { EST2 }\end{array}$ & $\begin{array}{l}\text { BAC06606 } \\
\text { QGT40748 }\end{array}$ & & $\begin{array}{l}20.49 \\
20.34\end{array}$ & $\begin{array}{l}313 \\
311\end{array}$ & $\begin{array}{l}34.4 \\
34.4\end{array}$ & $\begin{array}{c}\text { Di } \\
\text { Mono }\end{array}$ & $\begin{array}{l}90 \\
70\end{array}$ & $\begin{array}{c}7 \\
7.1\end{array}$ & $\begin{array}{l}\mathrm{C} 6 \\
\mathrm{C} 6\end{array}$ & $110^{c}$ & $109^{c}$ & $117^{\mathrm{c}}$ & & & $\begin{array}{c}{[59,61]} \\
{[60]}\end{array}$ \\
\hline \multicolumn{16}{|l|}{ Family V } \\
\hline Est4L & MT989339 & Uncultured bacterium & 100 & 267 & 30.1 & Tetra & 50 & 10.0 & $\mathrm{C} 10$ & $6.94^{\mathrm{a}}$ & $128.6^{\mathrm{a}}$ & $7.47^{\mathrm{a}}$ & \multirow{6}{*}{$\begin{array}{c}\mathrm{Mg}^{2+}, \\
\mathrm{Mn}^{2+} \\
\mathrm{Ca}^{2+}, \mathrm{Li}^{2+}, \\
\mathrm{Cd}^{2+} \\
\mathrm{Fe}^{2+}, \mathrm{Cd}^{2+}\end{array}$} & $\mathrm{Cu}^{2+}, \mathrm{Zn}^{2+}$ & This study \\
\hline Est16 & ADM63076 & Uncultured bacterium & 21.28 & 302 & 31.9 & Mono & 55 & 9.0 & $\mathrm{C} 4$ & & & & & $\mathrm{Zn}^{2+}$ & {$[50]$} \\
\hline QpeH & ANT80587 & Pseudomonas sp. J-5 & 17.67 & 309 & 38.5 & Mono & 30 & 8.0 & & & & & & $\mathrm{Mg}^{2+}$ & [51] \\
\hline LacH & AGS18892 & Brevundimonas sp. LY-2 & 12.46 & 306 & 32.4 & $\mathrm{Di}$ & 40 & 7.0 & $\mathrm{C} 2$ & & & & & $\mathrm{Zn}^{2+}, \mathrm{Hg}^{2+}$ & {$[52]$} \\
\hline $\mathrm{H} 8$ & ARH02619 & Uncultured bacterium & 17.33 & 305 & 32.8 & & 35 & 10.8 & $\mathrm{C} 6$ & $4.4^{\mathrm{d}}$ & $52.6^{\mathrm{d}}$ & $2.7^{\mathrm{d}}$ & & $\mathrm{Cu}^{2+}, \mathrm{Zn}^{2+}$ & [55] \\
\hline FCLip1 & ABL95965 & $\begin{array}{l}\text { Fervidobacterium } \\
\text { changbaicum }\end{array}$ & 10.64 & 315 & 35.9 & & 78 & 7.8 & $\mathrm{C} 10$ & $123.4^{\mathrm{d}}$ & & & & $\begin{array}{c}\mathrm{Cu}^{2+}, \mathrm{Ni}^{2+}, \\
\mathrm{Zn}^{2+}\end{array}$ & [56] \\
\hline
\end{tabular}

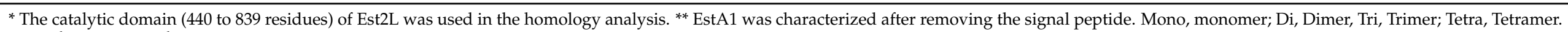
a $30 \%,{ }^{b} 15 \%,{ }^{c} 50 \%$, d $20 \%$; IPA, isopropyl alcohol; $\mathrm{MeOH}$, methanol; $\mathrm{ACN}$, acetonitrile. 
Est2L and Est4L were stable in 30\% methanol but inactivated in isopropanol or acetonitrile, similar to others reported, except for PestE, which was stable in all three solvents [59], EstA1, which was stable in methanol [58], and FCLip1, which was stable in isopropanol [56]. Little information about enantioselectivity was available. The selectivity of Est2L was weak and Est4L preferred S-form, while EST2 [60], PestE [61], and LacH [52] preferred R-form. Est2L was inhibited by $\mathrm{Cu}^{2+}$, similar to Est3K and Est22 [29,57], and Est4L was inhibited by $\mathrm{Cu}^{2+}$ and $\mathrm{Zn}^{2+}$, similar to $\mathrm{H} 8$ and FCLip1 $[55,56]$. On the other hand, the interactions of $\mathrm{CzcO}$ domain of Est2L with metal ions might be different from those of YiiP, a bacterial cation diffusion facilitator (CDF), which maintains cellular homeostasis of metal ions by transporting $\mathrm{Zn}^{2+}, \mathrm{Fe}^{2+}$, and $\mathrm{Cd}^{2+}$, and contains three binding sites and tetrahedral motifs [62]. In PMSF inhibition, Est2L was more sensitive than Est4L; inhibition of Est4L by PMSF increased with higher PMSF concentration, similar to the results of other family $\mathrm{V}$ esterases [45,49]. Inhibition became nearly complete with preincubation of Est4L and PMSF for $30 \mathrm{~min}$, suggesting that delayed inhibition might be related to accessibility of PMSF to the active site.

Microbial lipolytic fusion enzymes have received increasing attention due to their contributions to the achievement of improved properties and to the reduction of industrial costs [2]. Est2L is a naturally fused lipolytic enzyme. Therefore, the roles of the $\mathrm{CzcO}$ domain in Est2L should be investigated in further research in relation to the effects of $\mathrm{Zn}^{2+}$, $\mathrm{Co}^{2+}$, and $\mathrm{Cd}^{2+}$ on enzyme activity.

\section{Conclusions}

In this study, two novel esterase genes, est $2 \mathrm{~L}$ and est $4 \mathrm{~L}$, encoding intracellular Est2L and Est4L respectively, were characterized using transformants SKE2 and SKE4 respectively, isolated from a metagenomic library. Interestingly, Est2L was a unique fusion type of protein composed of a $\mathrm{CzcO}$ and an acetylesterase domain and belonged to family IV, whereas Est4L belonged to family V. The esterase domains of Est2L and Est4L showed low similarities to other enzymes characterized to date. Native Est2L and Est4L were found to be dimeric and tetrameric in form, respectively, and Est2L showed better heat stability than Est4L. Significant effects from $\mathrm{Co}^{2+}$ and $\mathrm{Zn}^{2+}$ were not observed in Est2L, even though it contains the domain $\mathrm{CzcD}$, which is related to the efflux of these ions. Est2L preferred shorter pNP-esters with a moderate BChE activity, whereas Est4L showed the highest activity with longer pNP-esters with a broad specificity. Est2L and Est4L showed high stabilities with methanol and Triton X-100. These enzymes could be used for a variety of applications, such as detergent or mining processing under alkaline conditions, due to their alkaline optimum and/or the possibility of biomarkers with $\mathrm{Cu}^{2+}$ sensitivity.

Supplementary Materials: The following are available online at https:/ /www.mdpi.com/article/10 .3390/app11135905/s1, Figure S1: BLASTp of Est2L (a) and Est4L (b), Figure 2: Multiple sequence alignments of a CzcO domain of Est2L (a), an acetylesterase domain of Est2L (b), and Est4L (c) using the Clustal W method in DNA/MAN.

Author Contributions: Conceptualization, J.K. and H.K.; cloning, S.K.K.; purification, H.W.L., G.S.J. and J.E.P.; analysis of enzymatic property, G.S.J. and J.E.P.; data curation, J.E.P.; writing-original draft preparation, J.E.P.; writing-review and editing, J.K. and H.K; supervision, H.K. All authors have read and agreed to the published version of the manuscript.

Funding: This research received no external funding.

Institutional Review Board Statement: Not applicable.

Informed Consent Statement: Not applicable.

Data Availability Statement: The data presented in this study are available on request from the corresponding author.

Conflicts of Interest: The authors declare no conflict of interest. 


\section{References}

1. Arpigny, J.L.; Jaeger, K.E. Bacterial lipolytic enzymes: Classification and properties. Biochem. J. 1999, 343, 177-183. [CrossRef] [PubMed]

2. Gudiukaite, R.; Gricajeva, A. Microbial lipolytic fusion enzymes: Current state and future perspectives. World J. Microbiol. Biotechnol. 2017, 33, 216. [CrossRef] [PubMed]

3. Priyanka, P.; Tan, Y.; Kinsella, G.K.; Henehan, G.T.; Ryan, B.J. Solvent stable microbial lipases: Current understanding and biotechnological applications. Biotechnol. Lett. 2019, 41, 203-220. [CrossRef] [PubMed]

4. Larsen, E.M.; Johnson, R.J. Microbial esterases and ester prodrugs: An unlikely marriage for combating antibiotic resistance. Drug Dev. Res. 2019, 80, 33-47. [CrossRef]

5. Gupta, R.; Gupta, N.; Rathi, P. Bacterial lipases: An overview of production, purification and biochemical properties. Appl. Microbiol. Biotechnol. 2004, 64, 763-781. [CrossRef]

6. Javed, S.; Azeem, F.; Hussain, S.; Rasul, I.; Siddique, M.H.; Riaz, M.; Afzal, M.; Kouser, A.; Nadeem, H. Bacterial lipases: A review on purification and characterization. Prog. Biophys. Mol. Biol. 2018, 132, 23-34. [CrossRef]

7. Parapouli, M.; Foukis, A.; Stergiou, P.Y.; Koukouritaki, M.; Magklaras, P.; Gkini, O.A.; Papamichael, E.M.; Afendra, A.S.; Hatziloukas, E. Molecular, biochemical and kinetic analysis of a novel, thermostable lipase (LipSm) from Stenotrophomonas maltophilia Psi-1, the first member of a new bacterial lipase family (XVIII). J. Biol. Res. Thessalon. 2018, 25, 4, reprinted in J. Biol. Res. Thessalon. 2018, 25, 10. [CrossRef]

8. Ollis, D.L.; Cheah, E.; Cygler, M.; Dijkstra, B.; Frolow, F.; Franken, S.M.; Harel, M.; Remington, S.J.; Silman, I.; Schrag, J.; et al. The alpha/beta hydrolase fold. Protein Eng. 1992, 5, 197-211. [CrossRef]

9. Handelsman, J.; Rondon, M.R.; Brady, S.F.; Clardy, J.; Goodman, R.M. Molecular biological access to the chemistry of unknown soil microbes: A new frontier for natural products. Chem. Biol. 1998, 5, R245-R249. [CrossRef]

10. Ogram, A.; Sayler, G.S.; Barkay, T. The extraction and purification of microbial DNA from sediments. J. Microbiol. Methods 1987, 7, 57-66. [CrossRef]

11. Rondon, M.R.; August, P.R.; Bettermann, A.D.; Brady, S.F.; Grossman, T.H.; Liles, M.R.; Loiacono, K.A.; Lynch, B.A.; MacNeil, I.A.; Minor, C.; et al. Cloning the soil metagenome: A strategy for accessing the genetic and functional diversity of uncultured microorganisms. Appl. Environ. Microbiol. 2000, 66, 2541-2547. [CrossRef] [PubMed]

12. Taberlet, P.; Coissac, E.; Hajibabaei, M.; Rieseberg, L.H. Environmental DNA. Mol. Ecol. 2012, 21, 1789-1793. [CrossRef]

13. Almeida, J.M.; Alnoch, R.C.; Souza, E.M.; Mitchell, D.A.; Krieger, N. Metagenomics: Is it a powerful tool to obtain lipases for application in biocatalysis? Biochim. Biophys. Acta. Proteins Proteom. 2020, 1868, 140320. [CrossRef] [PubMed]

14. Qiu, J.; Yang, H.; Yan, Z.; Shi, Y.; Zou, D.; Ding, L.; Shao, Y.; Li, L.; Khan, U.; Sun, S.; et al. Characterization of XtjR8: A novel esterase with phthalate-hydrolyzing activity from a metagenomic library of lotus pond sludge. Int. J. Biol. Macromol. 2020, 164, 1510-1518. [CrossRef]

15. Tutuncu, H.E.; Balci, N.; Tuter, M.; Karaguler, N.G. Recombinant production and characterization of a novel esterase from a hypersaline lake, Acıgöl, by metagenomic approach. Extremophiles 2019, 23, 507-520. [CrossRef]

16. Araujo, F.J.; Hissa, D.C.; Silva, G.O.; Antunes, A.S.L.M.; Nogueira, V.L.R.; Gonçalves, L.R.B.; Melo, V.M.M. A novel bacterial carboxylesterase identified in a metagenome derived-clone from Brazilian mangrove sediments. Mol. Biol. Rep. 2020, 47, 3919-3928. [CrossRef] [PubMed]

17. Jia, M.L.; Zhong, X.L.; Lin, Z.W.; Dong, B.X.; Li, G. Expression and characterization of an esterase belonging to a new family via isolation from a metagenomic library of paper mill sludge. Int. J. Biol. Macromol. 2019, 1, 1192-1200. [CrossRef]

18. Zhong, X.L.; Tian, Y.Z.; Jia, M.L.; Liu, Y.D.; Cheng, D.; Li, G. Characterization and purification via nucleic acid aptamers of a novel esterase from the metagenome of paper mill wastewater sediments. Int. J. Biol. Macromol. 2020, 15, 441-450. [CrossRef]

19. Wu, S.; Nan, F.; Jiang, J.; Qiu, J.; Zhang, Y.; Qiao, B.; Li, S.; Xin, Z. Molecular cloning, expression and characterization of a novel feruloyl esterase from a soil metagenomic library with phthalate-degrading activity. Biotechnol. Lett. 2019, 41, 995-1006. [CrossRef]

20. Almeida, J.M.; Martini, V.P.; Iulek, J.; Alnoch, R.C.; Moure, V.R.; Müller-Santos, M.; Souza, E.M.; Mitchell, D.A.; Krieger, N. Biochemical characterization and application of a new lipase and its cognate foldase obtained from a metagenomic library derived from fat-contaminated soil. Int. J. Biol. Macromol. 2019, 15, 442-454. [CrossRef]

21. Nan, F.; Jiang, J.; Wu, S.; Zhang, Y.; Qiu, J.; Qiao, B.; Li, S.; Xin, Z. A novel VIII carboxylesterase with high hydrolytic activity against ampicillin from a soil metagenomic library. Mol. Biotechnol. 2019, 61, 892-904. [CrossRef]

22. Sarkar, J.; Dutta, A.; Chowdhury, P.P.; Chakraborty, J.; Dutta, T.K. Characterization of a novel family VIII esterase EstM2 from soil metagenome capable of hydrolyzing estrogenic phthalates. Microb. Cell Fact. 2020, 24, 77. [CrossRef] [PubMed]

23. Qiu, J.; Zhang, Y.; Shi, Y.; Jiang, J.; Wu, S.; Li, L.; Shao, Y.; Xin, Z. Identification and characterization of a novel phthalate-degrading hydrolase from a soil metagenomic library. Ecotoxicol. Environ. Saf. 2020, 1, 110148. [CrossRef] [PubMed]

24. Gupta, V.; Singh, I.; Kumar, P.; Rasool, S.; Verma, V. A hydrolase with esterase activity expressed from a fosmid gene bank prepared from DNA of a North West Himalayan glacier frozen soil sample. 3 Biotech 2019, 9, 107. [CrossRef] [PubMed]

25. Wong, D.W.S.; Chan, V.J.; Liao, H. Metagenomic discovery of feruloyl esterases from rumen microflora. Appl. Microbiol. Biotechnol. 2019, 103, 8449-8457. [CrossRef]

26. Lu, M.; Dukunde, A.; Daniel, R. Biochemical profiles of two thermostable and organic solvent-tolerant esterases derived from a compost metagenome. Appl. Microbiol. Biotechnol. 2019, 103, 3421-3437. [CrossRef] [PubMed] 
27. Park, J.M.; Kang, C.H.; Won, S.M.; Oh, K.H.; Yoon, J.H. Characterization of a novel moderately thermophilic solvent-tolerant esterase isolated from a compost metagenome library. Front Microbiol. 2020, 24, 3069. [CrossRef]

28. Kasmaei, K.M.; Sundh, J. Identification of novel putative bacterial feruloyl esterases from anaerobic ecosystems by use of whole-genome shotgun metagenomics and genome binning. Front Microbiol. 2019, 20, 2673. [CrossRef]

29. Kim, H.J.; Jeong, Y.S.; Jung, W.K.; Kim, S.K.; Lee, H.W.; Kahng, H.Y.; Kim, J.; Kim, H. Characterization of novel family IV esterase and family I.3 lipase from an oil-polluted mud flat metagenome. Mol. Biotechnol. 2015, 7, 781-792. [CrossRef]

30. Anton, A.; Grosse, C.; Reissmann, J.; Pribyl, T.; Nies, D.H. CzcD is a heavy metal ion transporter involved in regulation of heavy metal resistance in Ralstonia sp. strain CH34. J. Bacteriol. 1999, 181, 6876-6881. [CrossRef]

31. Guffanti, A.A.; Wei, Y.; Rood, S.V.; Krulwich, T.A. An antiport mechanism for a member of the cation diffusion facilitator family: Divalent cations efflux in exchange for $\mathrm{K}^{+}$and $\mathrm{H}^{+}$. Mol. Microbiol. 2002, 45, 145-153. [CrossRef] [PubMed]

32. Kim, H.J.; Jung, W.K.; Lee, H.W.; Yoo, W.; Kim, T.D.; Kim, H. Characterization of an alkaline family I.4 lipase from Bacillus sp. W130-35 isolated from a tidal mud flat with broad substrate specificity. J. Microbiol. Biotechnol. 2015, 25, 2024-2033. [CrossRef] [PubMed]

33. Kumar, S.; Stecher, G.; Li, M.; Knyaz, C.; Tamura, K. MEGA X: Molecular evolutionary genetics analysis across computing platforms. Mol. Biol. Evol. 2018, 35, 1547-1549. [CrossRef] [PubMed]

34. Lee, J.P.; Kang, M.G.; Lee, J.Y.; Oh, J.M.; Baek, S.C.; Leem, H.H.; Park, D.; Cho, M.L.; Kim, H. Potent inhibition of acetylcholinesterase by sargachromanol I from Sargassum siliquastrum and by selected natural compounds. Bioorg. Chem. 2019, 89, 103043. [CrossRef]

35. Laemmli, U.K. Cleavage of structural proteins during the assembly of the head of bacteriophage T4. Nature 1970, 227, 680-685. [CrossRef]

36. Bradford, M.M. A rapid and sensitive method for the quantitation of microgram quantities of protein utilizing the principle of protein-dye binding. Anal. Biochem. 1976, 72, 248-254. [CrossRef]

37. Ngo, T.D.; Ryu, B.H.; Ju, H.; Jang, E.J.; Kim, K.K.; Kim, T.D. Crystallographic analysis and biochemical applications of a novel penicillin-binding protein/ $\beta$-lactamase homologue from a metagenomic library. Acta Crystallogr. D Biol. Crystallogr. 2014, 70, 2455-2466. [CrossRef]

38. Krintel, C.; Klint, C.; Lindvall, H.; Mörgelin, M.; Holm, C. Quarternary structure and enzymological properties of the different hormone-sensitive lipase (HSL) isoforms. PLoS ONE 2010, 17, e11193. [CrossRef] [PubMed]

39. Kim, T.D. Bacterial hormone-sensitive lipases (bHSLs): Emerging enzymes for biotechnological applications. J. Microbiol. Biotechnol. 2017, 28, 1907-1915. [CrossRef]

40. Smith, A.J.; Sanders, M.A.; Juhlmann, B.E.; Hertzel, A.V.; Bernlohr, D.A. Mapping of the hormone-sensitive lipase binding site on the adipocyte fatty acid-binding protein (AFABP). Identification of the charge quartet on the AFABP/aP2 helix-turn-helix domain. J. Biol. Chem. 2008, 28, 33536-33543. [CrossRef] [PubMed]

41. Mandrich, L.; Merone, L.; Pezzullo, M.; Cipolla, L.; Nicotra, F.; Rossi, M.; Manco, G. Role of the N terminus in enzyme activity, stability and specificity in thermophilic esterases belonging to the HSL family. J. Mol. Biol. 2005, 21, 501-512. [CrossRef]

42. Nies, D.H. CzcR and $\mathrm{CzcD}$, gene products affecting regulation of resistance to cobalt, zinc, and cadmium (czc system) in Alcaligenes eutrophus. J. Bacteriol. 1992, 174, 8102-8110. [CrossRef] [PubMed]

43. Zha, D.; Zhang, H.; Zhang, H.; Xu, L.; Yan, Y. N-terminal transmembrane domain of lipase LipA from Pseudomonas protegens Pf-5: A must for its efficient folding into an active conformation. Biochimie 2014, 105, 165-171. [CrossRef] [PubMed]

44. Khudary, R.A.; Venkatachalam, R.; Katzer, M.; Elleuche, S.; Antranikian, G. A cold-adapted esterase of a novel marine isolate, Pseudoalteromonas arctica: Gene cloning, enzyme purification and characterization. Extremophiles 2010, 14, 273-285. [CrossRef]

45. Jensen, M.V.; Horsfall, L.E.; Wardrope, C.; Togneri, P.D.; Marles-Wright, J.; Rosser, S.J. Characterisation of a new family of carboxyl esterases with an OsmC domain. PLoS ONE 2016, 16, e0166128. [CrossRef]

46. Ranjan, R.; Yadav, M.K.; Suneja, G.; Sharma, R. Discovery of a diverse set of esterases from hot spring microbial mat and sea sediment metagenomes. Int. J. Biol. Macromol. 2018, 119, 572-581. [CrossRef]

47. Nam, K.H.; Kim, M.Y.; Kim, S.J.; Priyadarshi, A.; Kwon, S.T.; Koo, B.S.; Yoon, S.H.; Hwang, K.Y. Structural and functional analysis of a novel hormone-sensitive lipase from a metagenome library. Proteins Struct. Funct. Bioinform. 2009, 74, 1036-1040. [CrossRef]

48. Benavente, R.; Esteban-Torres, M.; Acebrón, I.; de Las Rivas, B.; Muñoz, R.; Alvarez, Y.; Mancheño, J.M. Structure, biochemical characterization and analysis of the pleomorphism of carboxylesterase Cest-2923 from Lactobacillus plantarum WCFS1. FEBS J. 2013, 280, 6658-6671. [CrossRef]

49. Virk, A.P.; Sharma, P.; Capalash, N. A new esterase, belonging to hormone-sensitive lipase family, cloned from Rheinheimera sp. isolated from industrial effluent. J. Microbiol. Biotechnol. 2011, 21, 667-674. [CrossRef]

50. Pereira, M.R.; Mercaldi, G.F.; Maester, T.C.; Balan, A.; Lemos, E.G. Est16, a new esterase isolated from a metagenomic library of a microbial consortium specializing in diesel oil degradation. PLoS ONE 2015, 10, e0133723. [CrossRef]

51. Zhang, H.; Li, M.; Li, J.; Wang, G.; Liu, Y. Purification and properties of a novel quizalofop-p-ethyl-hydrolyzing esterase involved in quizalofop-p-ethyl degradation by Pseudomonas sp. J-2. Microb. Cell Fact. 2017, 16, 80. [CrossRef]

52. Zhang, J.; Zhao, M.; Yu, D.; Yin, J.; Zhang, H.; Huang, X. Biochemical characterization of an enantioselective esterase from Brevundimonas sp. LY-2. Microb. Cell Fact. 2017, 16, 112. [CrossRef]

53. Huo, Y.Y.; Rong, Z.; Jian, S.L.; Xu, C.D.; Li, J.; Xu, X.W. A Novel halotolerant thermoalkaliphilic esterase from marine bacterium Erythrobacter seohaensis SW-135. Front Microbiol. 2017, 22, 2315. [CrossRef] [PubMed] 
54. Byun, J.S.; Rhee, J.K.; Kim, N.D.; Yoon, J.; Kim, D.U.; Koh, E.; Oh, J.W.; Cho, H.S. Crystal structure of hyperthermophilic esterase EstE1 and the relationship between its dimerization and thermostability properties. BMC Struct. Biol. 2007, 7, 47. [CrossRef] [PubMed]

55. Zhang, Y.; Hao, J.; Zhang, Y.Q.; Chen, X.L.; Xie, B.B.; Shi, M.; Zhou, B.C.; Zhang, Y.Z.; Li, P.Y. Identification and characterization of a novel salt-tolerant esterase from the deep-Sea sediment of the south china sea. Front. Microbiol. 2017, 8, 441. [CrossRef] [PubMed]

56. Cai, J.; Xie, Y.; Song, B.; Wang, Y.; Zhang, Z.; Feng, Y. Fervidobacterium changbaicum Lip1: Identification, cloning, and characterization of the thermophilic lipase as a new member of bacterial lipase family V. Appl. Microbiol. Biotechnol. 2011, 89, 1463-1473. [CrossRef] [PubMed]

57. Huang, J.; Huo, Y.Y.; Ji, R.; Kuang, S.; Ji, C.; Xu, X.W.; Li, J. Structural insights of a hormone sensitive lipase homologue Est22. Sci. Rep. 2016, 6, 28550. [CrossRef] [PubMed]

58. Won, S.J.; Jeong, H.B.; Kim, H.K. Characterization of novel salt-tolerant esterase isolated from the marine bacterium Alteromonas sp. 39-G1. J. Microbiol. Biotechnol. 2020, 30, 216-225. [CrossRef]

59. Hotta, Y.; Ezaki, S.; Atomi, H.; Imanaka, T. Extremely stable and versatile carboxylesterase from a hyperthermophilic archaeon. Appl. Environ. Microbiol. 2002, 68, 3925-3931. [CrossRef] [PubMed]

60. De Simone, G.; Galdiero, S.; Manco, G.; Lang, D.; Rossi, M.; Pedone, C. A snapshot of a transition state analogue of a novel thermophilic esterase belonging to the subfamily of mammalian hormone-sensitive lipase. J. Mol. Biol. 2000, 303, 761-771. [CrossRef] [PubMed]

61. Palm, G.J.; Fernández-Álvaro, E.; Bogdanović, X.; Bartsch, S.; Sczodrok, J.; Singh, R.K.; Böttcher, D.; Atomi, H.; Bornscheuer, U.T.; Hinrichs, W. The crystal structure of an esterase from the hyperthermophilic microorganism Pyrobaculum calidifontis VA1 explains its enantioselectivity. Appl. Microbiol. Biotechnol. 2011, 91, 1061-1072. [CrossRef] [PubMed]

62. Cotrim, C.A.; Jarrott, R.J.; Martin, J.L.; Drew, D. A structural overview of the zinc transporters in the cation diffusion facilitator family. Acta Cryst. 2019, D75, 357-367. [CrossRef] [PubMed] 